\title{
The Development of Diabetes Following Coxsackie B Virus Infection in Mice
}

\author{
T.J. Coleman, K.W. Taylor and D.R. Gamble \\ Public Health Laboratory, West Park Hospital, Epsom, Surrey, and Department of Biochemistry, University of Sussex, \\ Falmer, Brighton, Sussex, England \\ Received: March 14, 1974 and in revised form: August 3, 1974
}

Summary. Diabetes was induced in $20-30 \%$ of adult CDl mice 15-20 days after infection by a tissue culture propagated strain of Coxsackie B4 virus. Serum insulin and insulin release from isolated islets indicated a relative insulin deficiency in diabetic animals. In some animals diabetes appeared to be permanent whilst in many it was of a temporary nature. Histology showed only slight damage in both islet and acinar tissue. Infection with pancreas and heart adapted strains of Coxsackie B3 virus failed to produce diabetes in mice and, in contrast to the effects of Coxsackie B4, severe acinar cell damage was seen.

Key words: Virus-induced diabetes, Coxsackie B4 virus, Coxsackie B3 virus, islet cell damage, CDI mice, pancreas.
There have been several reports of a seasonal pattern associated with the onset of acute juvenile diabetes $[1-3]$. In these surveys an increased incidence of diabetes occurred during the autumn and winter months and among the possible explanations for these findings is an association between the onset of diabetes and virus infections at these times of year. Craighead and McLane [4] reported the first experimental evidence for virus induced diabetes when they demonstrated that a heart adapted strain ('M' strain) of EMC virus could produce localised islet cell damage and acute diabetes in certain strains of mouse. Structural damage to the islets of Langerhans in mice as a result of Coxsackie $\mathrm{B} 1, \mathrm{~B} 3$ and $\mathrm{B} 4$ virus infection has also been recorded $[5,6,7,8]$.

We have previously reported random blood sugar changes in CD1 mice following Coxsackie B4 virus infection [7] and we now report additional data on changes in weight, glucose tolerance, serum insulin concentration, and insulin release from isolated islet preparations, in mice infected with Coxsackie B viruses.

\section{Materials and Methods}

\section{Viruses}

Prototype Coxsackie B virus strains were used either as unmodified virus propagated in tissue culture, or after adaptation by passage through heart (M strain) or pancreas ( $P$ strain) in young mice. Virus suspensions were titrated in suckling mice and an intraperitoneal dose of 100 LD 50 was used for inoculation of adult mice. Control animals received sterile tissue culture fluid only. Suffixes P8 and P14 refer to the number of pancreatic passages and M12 indicates 12 passages through heart tissue in mice.

\section{Mice}

8-10 week old male mice were used throughout the investigation. Porton mice were obtained from stock bred at the University of Sussex, England, whilst random bred CD1 and DBA animals were obtained from Charles River Mouse Farms. Mice had free access to food (Oxoid Diet 41B) and water except for the $12 \mathrm{~h}$ prior to glucose tolerance testing when food was withheld.

\section{Preparation of Isolated Islets of Langerhans}

Islets were prepared by collagenase digestion of pancreases [9]. After isolation the islets were pre-incubated at $37^{\circ} \mathrm{C}$ for $30 \mathrm{~min}$ in a bicarbonate buffered medium [10] previously gassed with a mixture of $95 \%$ oxygen and $5 \%$ carbon dioxide and containing $2 \mathrm{mM}$ glucose. After washing in fresh buffer two islets were incubated for $30 \mathrm{~min}$ at $37^{\circ} \mathrm{C}$ in $1 \mathrm{ml}$ of the bicarbonate buffer containing glucose at a concentration of either $2 \mathrm{mM}$ (low glucose) or $20 \mathrm{mM}$ (high glucose).

Following incubation the medium was sampled and its insulin content assayed by radioimmunoassay [11]. Results are expressed as $\mu U$ insulin released/islet/30. min incubation.

\section{Blood Sugar and Serum Insulin Estimations}

Blood sugar levels were estimated using the GODPerid method (Boehringer Mannheim GmbH), absorption being measured at $420 \mathrm{~m} \mu$ using a Gilford. 300-N automatic spectrophotometer. Prior to glucose tolerance testing each mouse was fasted for $12 \mathrm{~h}$ and a blood sample taken from the tail vein before administration of the glucose. Mice were weighed and inoculated intraperitoneally with $1 \mathrm{mg}$ of glucose per $\mathrm{g}$ body weight as a $10 \%$ solution prepared in isotonic saline.

Blood for serum insulin estimations was obtained 
from the brachial vessels and insulin levels were measured by a radioimmunoassay procedure [11] using human insulin standards. Over the range of insulin measurements recorded in this paper the displacement curves for mouse and human insulins in the radioimmunoassay were superimposable.

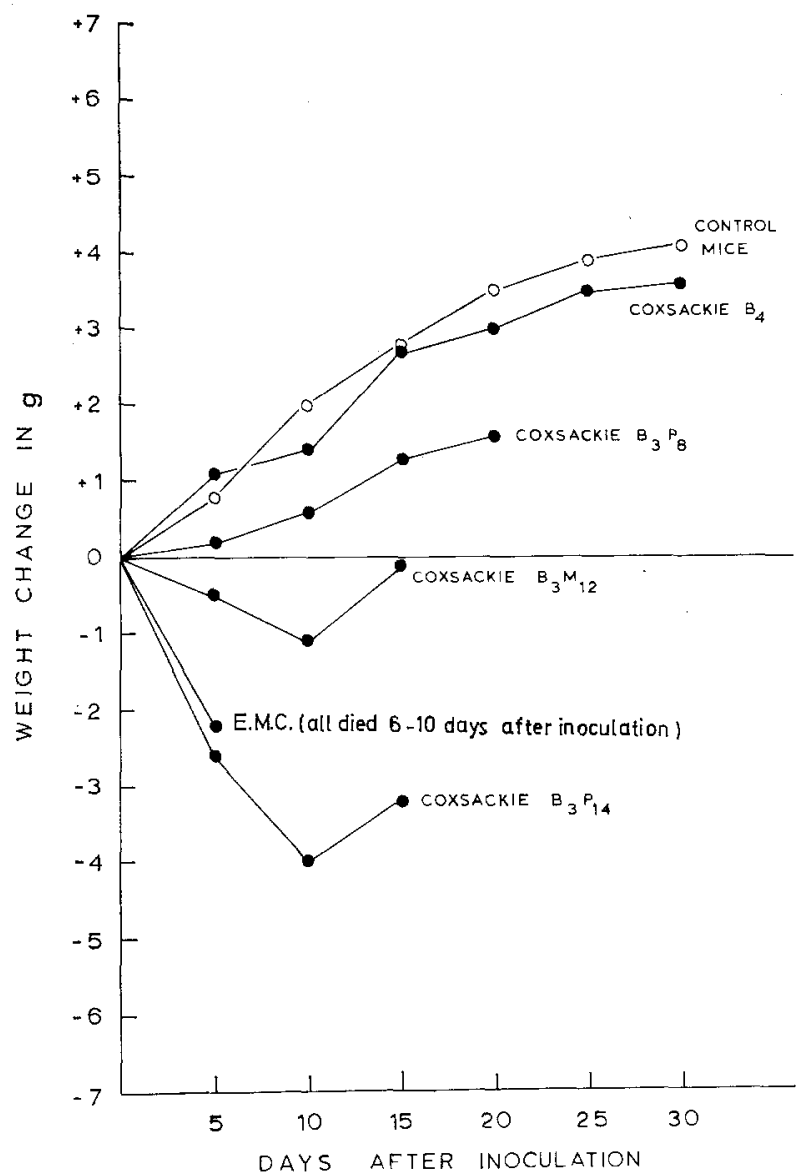

Fig. 1. Average weight changes in 8-10 weeks old CD1 mice after inoculation with an unadapted prototype strain of Coxsackie B4 virus, pancreas and heart adapted strains of Coxsackie B3 virus, and an unmodified strain of E.M.C. virus. Each point represents the mean weight change of at least 6 animals

\section{Results}

Mice inoculated with unadapted Coxsackje B4 virus showed only a slight reduction in weight gain compared with control animals whilst animals receiving Coxsackie virus B3 P14 showed marked weight loss and failed to regain their pre-inoculated weight within 15 days of infection (Fig. 1). The change in weight seemed to parallel the degree of acinar cell damage seen histologically.

Those animals dying after infection generally did so within seven days of inoculation (Table 1 ).

Mice infected with unadapted Coxsackie B4 virus showed only slight acinar cell changes but there was some $\mathrm{B}$ cell degeneration accompanied by a mononu- clear cell infiltration within and surrounding the affected islets (Fig. 2). These changes were found in those infected mice with a diminished glucose tolerance but not in control mice. Severe acinar cell damage was seen in mice infected with Coxsackie B3 virus but no hyperglycaemia ensued.

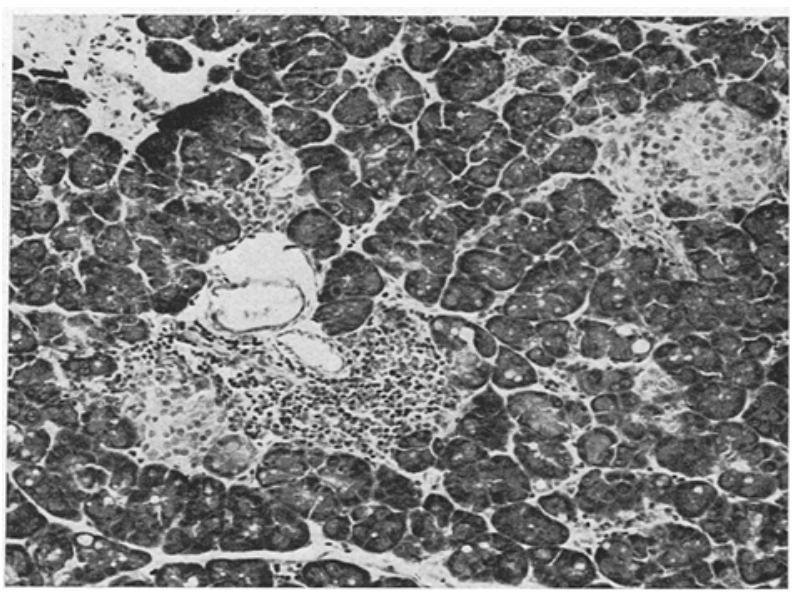

a

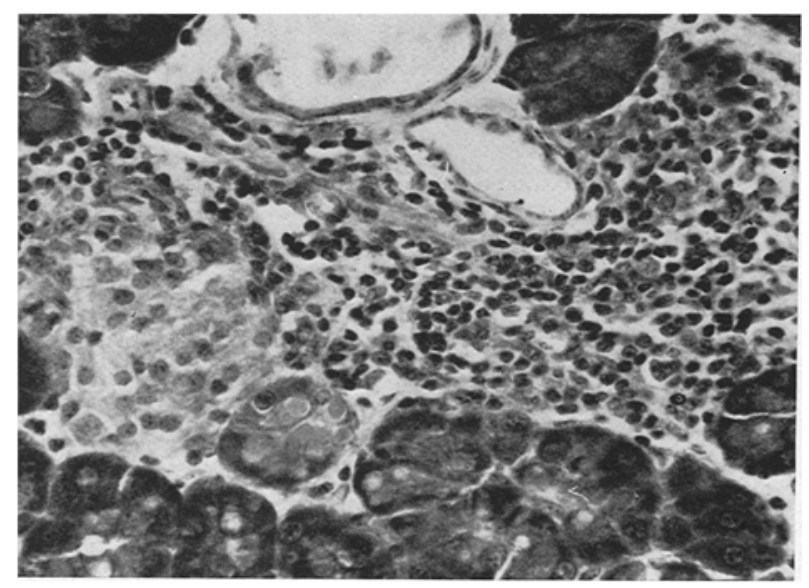

b

Fig. 2. Section of pancreas from a CD1 mouse infected with an unadapted Coxsackie B4 virus. The acinar cells appear normal but there is loss of architecture within the islet and mononuclear cells can be seen around and penetrating the islet tissue. (a) Section $\times 200$, (b) Section. $\times 500$

Table 1. Percentage mortality in mice following inoculation with an unadapted prototype strain of Coxackie B4 virus, pancreas and heart adapted strains of Coxsackie B3 virus, and an unmodified strain of E.M.C. virus

\begin{tabular}{lcclll}
\hline $\begin{array}{l}\text { Mouse } \\
\text { strain }\end{array}$ & $\begin{array}{l}\text { Cox } \\
\text { B3P8 }\end{array}$ & $\begin{array}{l}\text { Cox } \\
\text { B3P14 }\end{array}$ & $\begin{array}{l}\text { Cox } \\
\text { B3M12 }\end{array}$ & $\begin{array}{l}\text { Cox B4 } \\
\text { prototype }\end{array}$ & E.M.C. \\
\hline Porton & $10-15$ & - & - & - & \\
DBA & $15-25$ & - & $5-10$ & - & $90-100$ \\
CD1 & $5-10$ & $15-20$ & $0-5$ & $0-5$ & $90-100$ \\
\hline
\end{tabular}




\section{Blood Sugar Changes}

Fig. 3 shows the random blood sugar levels in CD1. mice after inoculation with unadapted Coxsackie B4 virus. The mean random blood sugar level in 98 control mice was $103 \mathrm{mg} / 100 \mathrm{ml}$ and mice with blood sugar levels more than 3 standard deviations above this mean were considered diabetic; using this criterion none of the controls was found to be diabetic. A small fall in the mean random blood sugar 5 days after inoculation was found, the control value being $105 \pm 6.8 \mathrm{mg} / 100 \mathrm{ml}$

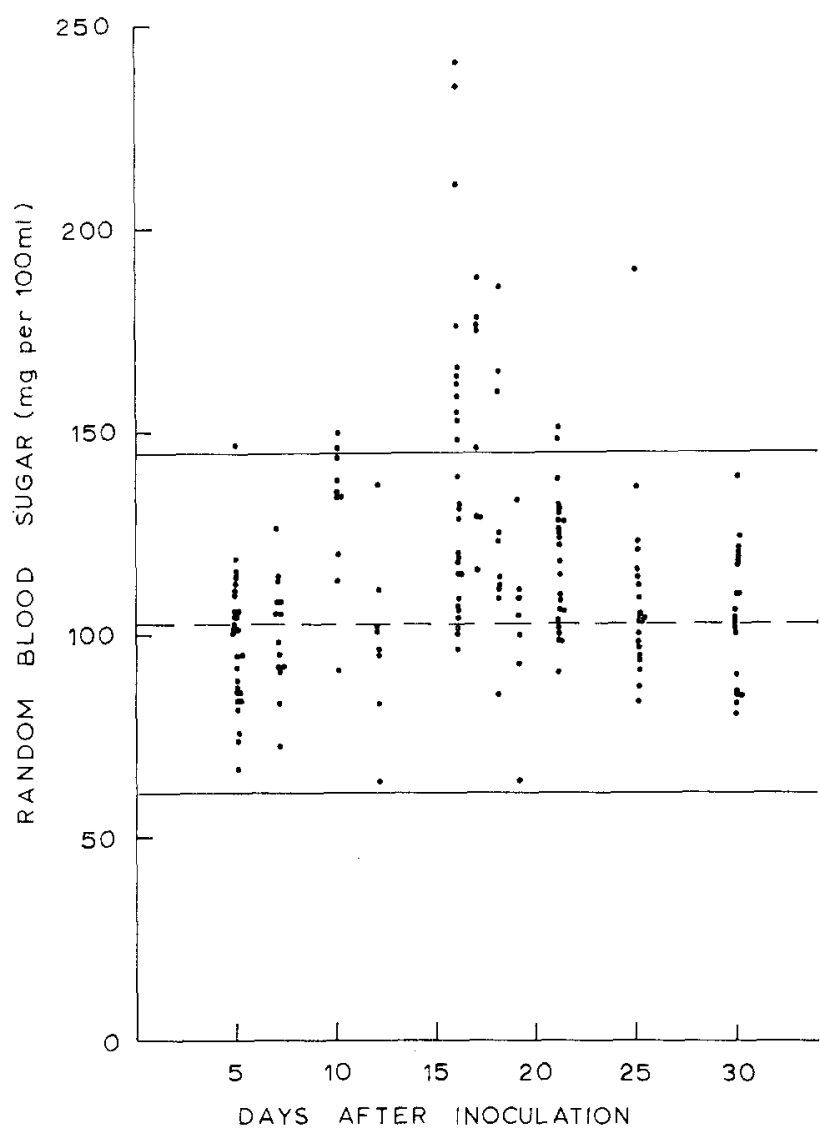

Fig. 3. Random blood sugar measurements $(\mathrm{mg} / 100 \mathrm{ml})$ in CD1 mice infected with unadapted Coxsackie B4 virus. The normal mean random blood sugar $\pm 3 \mathrm{SD}$ is shown by the horizontal lines

compared with $93 \pm 3.5 \mathrm{mg} / 100 \mathrm{ml}$ in infected mice. The maximum incidence of diabetes occurred between 15 and 20 days after inoculation, and affected between 20 and $30 \%$ of the infected animals. In mice infected with Coxsackie B3 P8 virus, blood sugar levels were consistently lower than in controls, except for one mouse which had a random blood sugar level of $195 \mathrm{mg} /$ $100 \mathrm{ml} 20$ days after infection.

Fig. 4 shows the results of intraperitoneal glucose tolerance tests on CD1 mice after unadapted Coxsackie B4 virus infection. Glucose tolerance in infected mice remained normal until about 12 days after inoculation when some mice showed diabetic responses. The glucose tolerance of four of these diabetic mice was monitored 30 days after infection, glucose intolerance persisted although some recovery was apparent. However, by 10 weeks after inoculation only one of the four animals remained frankly diabetic.

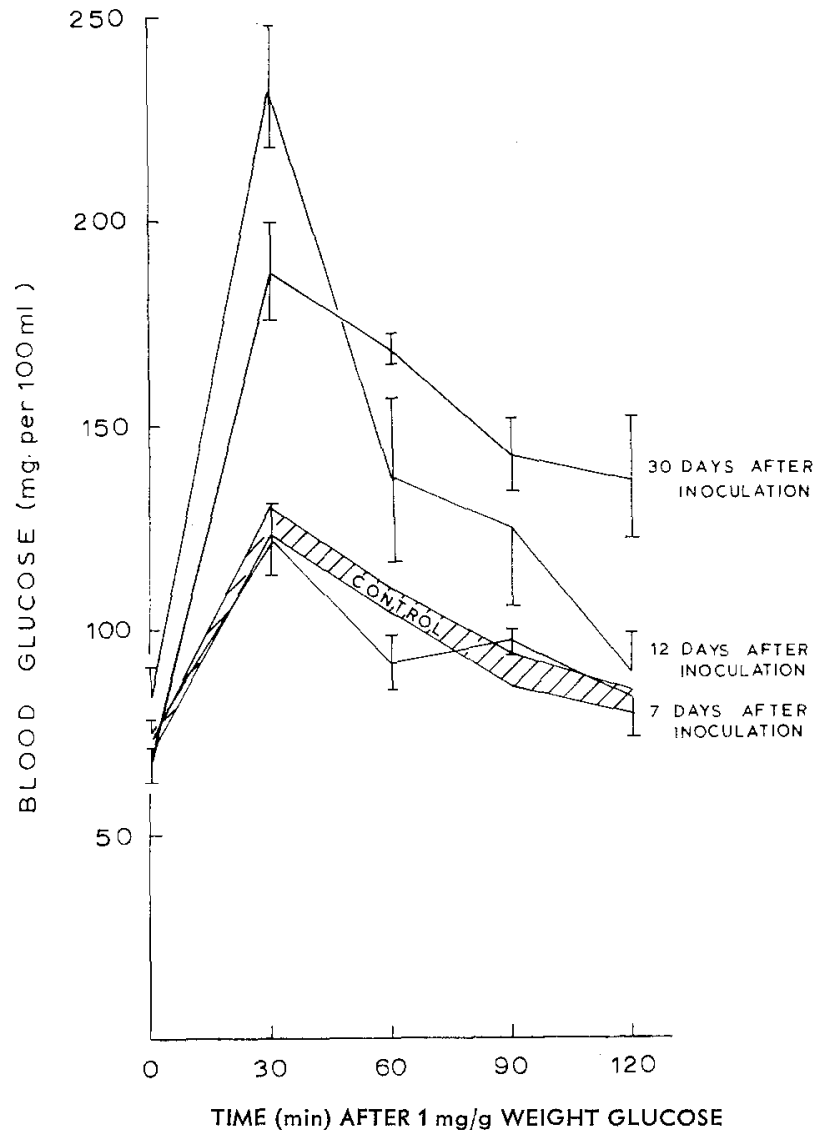

Fig. 4. Results of intraperitoneal glucose tolerance tests on CD1 mice infected by unadapted Coxsackie B4 virus 7, 12 and 30 days after inoculation (mean + SEM). The control glucose tolerance for 10 week old male CD1 mice is shown as the shaded area representing the normal mean 士SEM. 12 mice were tested at 7 days, 6 at 12 days, and 4 at 30 days. Control values were based on 78 mice at 0 min, 79 at $30 \mathrm{~min}, 42$ at $60 \mathrm{~min}, 31$ at $90 \mathrm{~min}$, and 28 at $120 \mathrm{~min}$

In other experiments in which different strains of mouse and virus were studied blood sugar levels were often depressed 5 days after infection but subsequently returned to normal [7].

\section{Serum Insulin Changes}

Random serum insulin levels in CD1 mice after unadapted Coxsackie B4 virus infection are shown in Table 2. Whilst the insulin concentrations in infected animals were higher than those in control mice, levels in mice with random blood sugars exceeding $160 \mathrm{mg} /$ 
$100 \mathrm{ml}$ were inappropriately low, denoting an impaired response of the $\mathbf{B}$ cell to a rising blood sugar.

\section{Secretion of Insulin from Isolated Islets of Langerhans}

Secretion of insulin was studied in islets of Langerhans isolated from CD1 mice 17 days after inoculation with Coxsackie B4 virus (Table 3). Islets from diabetic animals had normal basal rates of insulin release but undersecreted in response to high glucose stimulation. In earlier experiments with pancreas slices ob. tained from animals infected with pancreas adapted

Table 2. Random serum insulin levels $(\mu U / m l)$ in $C D 1$ mice following infection by unadapted Coxsackie B4 virus. Results are expressed as Mean $\pm S E M$. Number of observations in parentheses

\begin{tabular}{|c|c|c|c|}
\hline $\begin{array}{l}\text { Days } \\
\text { after in- } \\
\text { oculation }\end{array}$ & $\begin{array}{l}\text { Control } \\
\text { Mice }\end{array}$ & $\begin{array}{l}\text { Infected Mice } \\
\text { with blood sugar } \\
\text { less than } \\
160 \mathrm{mg} / 100 \mathrm{ml}\end{array}$ & $\begin{array}{l}\text { Infected Mice } \\
\text { with blood sugar } \\
\text { greater than } \\
160 \mathrm{mg} / 100 \mathrm{ml}\end{array}$ \\
\hline 0 & $\begin{array}{l}15 \pm 3.2 \\
(9)\end{array}$ & - & - \\
\hline 5 & $\frac{16 \pm 3.3}{(10)}$ & $28 \pm 5.6$ & - \\
\hline 10 & $\begin{array}{l}13 \pm 1.8 \\
(6)\end{array}$ & $\begin{array}{l}18 \pm 2.4 \\
(6)\end{array}$ & - \\
\hline 12 & $\begin{array}{l}16 \pm 2.7 \\
(10)\end{array}$ & $\begin{array}{l}26 \pm 4.0 \\
(6)\end{array}$ & 一 \\
\hline 17 & $\begin{array}{l}17 \pm 1.6 \\
(9)\end{array}$ & $\begin{array}{l}20 \pm 2.5 \\
(8)\end{array}$ & $\begin{array}{l}37 \pm 4.8 \\
(6)\end{array}$ \\
\hline 25 & $\begin{array}{l}17 \pm 2.1 \\
(5)\end{array}$ & $\begin{array}{l}23 \pm 2.8 \\
(8)\end{array}$ & $\begin{array}{l}43 \\
(1)\end{array}$ \\
\hline 30 & $\begin{array}{l}20 \pm 2.3 \\
(8)\end{array}$ & $\begin{array}{l}17 \pm 2.1 \\
(8)\end{array}$ & $\rightarrow$ \\
\hline
\end{tabular}

Table 3. Insulin secretion ( $\mu$ U/islet $/ 30 \mathrm{~min}$ ) from islets of Langerhans isolated from diabetic mice 17 days following infection with unadapted Coxsackie B4 virus. Results are expressed as Mean $\pm S E M$. Number of observations in parentheses

\begin{tabular}{lrr}
\hline $\begin{array}{l}\text { Glucose } \\
\text { concentration }\end{array}$ & $\begin{array}{l}\text { Insulin secretion } \mu \mathrm{U} / \text { islet } / 30 \mathrm{~min} \\
\text { Cox. B4 }\end{array}$ \\
\hline $2 \mathrm{mM}$ & & \\
$20 \mathrm{mM}$ & $54 \pm 4.6(23)$ & $46 \pm 5.0(29)$ \\
\hline
\end{tabular}

strains of Coxsackie B3 virus, the insulin response to high glucose stimulation was also less than that in controls. On the other hand the basal release rate was higher than in controls due perhaps to $B$ cell damage by enzymes leaking from damaged acinar tissue during incubation.

\section{Glucosuria, Ketonuria and Albuminuria}

The urine of both control and infected animals was routinely tested for glucose, ketones and albumin using ,Labstix' (Ames Co., Stoke Poges, England). Slight albuminuria was present in all mice tested but it was often heavy in mice infected with the pancreas adapted strains of Coxsackie B3 virus. The normal renal threshold for CD1 mice probably exceeds $200 \mathrm{mg} / 100 \mathrm{ml}$ and glucosuria was not consistently found even in mice with diabetes, but in some mice infected with Coxsackie B3 strains, haematuria and glycosuria were present even though blood sugar values were as low as $25 \mathrm{mg} / 100 \mathrm{ml}$. Ketonuria was not detected in any mouse.

\section{Discussion}

These experiments show that diabetes may follow the inoculation of susceptible mice with Coxsackie B4 virus, a common human pathogen, which seems to directly affect the function of islet cells. Craighead [4] described in similar condition in mice infected with EMC virus but this virus only rarely infects man. However, after infection of mice with pleurodynia virus (P.L.5), Robertson [12] found that although acinar cell changes were most marked, the islets seemed eventually to be strangled by fibrous tissue and that considerable elevation of blood sugar levels was occasionally. seen.

Random blood sugar levels of mice showed a biphasic response after infection. Initially there is a lowering of the blood glucose $3-5$ days after infection followed either by a return to normal level or by hyperglycaemia in $20-30 \%$ of animals. The maximum incidence of hyperglycaemia was seen $15-20$ days after infection. A biphasic response has also been noted in the blood sugars of mice infected with the heart adapted strain of E.M.C. virus [13-14]. The pattern of response in such mice, however, varied from our own in that a rise in random blood sugar was seen 2 days after inoculation followed by a return to near control levels and a further increase in blood glucose occurred 1-2 weeks later.

The hyperglycaemia and impaired glucose tolerance reported in this study appears to be due to a defect in the secretory capacity of islets, which cannot respond to glucose appropriately (Tables 2 and 3 ). The nature of this impaired responsiveness to islets is at present uncertain, although the change appears to be partly reversible over a period of time, leading to an improvement in glucose tolerance after 30 days (Fig. 4). It is not known whether changes induced by the virus are seen only in the secretory mechanism, or perhaps involve insulin synthesis as well.

The mechanisms by which further degeneration of islets might continue are unclear, but involvement of an immunological process or the activation of a latent viral activity are possible explanations. Cases of juvenile type diabetes frequently require quite small amounts of insulin initially after the acute effects of severe hyperglycaemia and ketosis have been corrected, but over a period of a few months after diagnosis their insulin requirement gradually increases, reaching levels consistent with a total lack of endogenous insulin production. If human diabetes had a viral aetiology such cases would be compatible with continuing islet cell damage after the initial acute precipitating incident. 
The islets from hyperglycaemic mice inoculated 2-3 weeks previously often appeared smaller than normal. In a few animals killed 3-4 months after infection a mixed picture was seen. The pancreases of some animals appeared to have recovered completely, but in others the total B cell mass was located within a few very large islets which may indicate a reactive hyperplasia similar to that described in partially pancreatectomised rats [15].

The experiments demonstrate the critical nature of both host and environmental factors. In the case of mice infected with the P8 strain of Coxsackie B3 virus the acinar cell damage was severe in $8-10$ weeks old DBA mice, but relatively mild in CD1 mice of a similar age. Further adaptation of the pancreatic strain of Coxsackie B3 virus only seemed to increase its tropism towards the acinar cells in CD1 mice whilst leaving the islets intact. Also adaptation of Coxsackie B3 virus to heart muscle reduced its ability to produce pancreatitis. Sex differences in susceptibility to EMC virus have also been noted [16]; whether these differences indicate a genetic component located on the $\mathrm{Y}$ chromosome allowing a predisposition to diabetogenic influences, or whether the hormonal environment is the critical factor in permitting the development of diabetes in these animals, remains uncertain.

It is of interest that the observations of the incidence of diabetes in mice after EMC virus infection is similar to the incidence after Coxsackie B4 virus infection. In both models some hyperglycaemic mice show an improvement in glucose tolerance whilst others appear to remain diabetic for many months and it is tempting to propose that the pathogenesis of diabetes due to both these viruses may involve similar mechanisms.

Diabetes in man appears to result from a complex interplay between genetic and environmental factors [17], and clearly viruses may be implicated in its aetiology. At present there is some evidence based on. epidemiological and antibody studies that Coxsackie $B 4$ virus infection may be associated with the onset of some cases of juvenile diabetes [18]. It is important therefore to define the precise nature of the damage to islets of Langerhans by coxsackie virus in animals since these changes could elosely simulate changes seen in the early stages of diabetes in man. Coxsackie virus induced diabetes in mice may serve as an appropriate model for such studies.

Acknowledgements. We are grateful to the British Diabetic Association and the Wellcome Trust for financial support, which enabled these investigations to be carried out.

\section{References}

1. Adams, S.F.: The seasonal variation in the onset of acute diabetes; the age and sex factors in 1000 diabetic patients. Arch. intern. Med. 37, 861 - 865 (1926)

2. Danowski, T.S.: Diabetes mellitus, with emphasis on children and young adults, p 129. Baltimore: Williams \& Wilkins 1957

3. Gamble, D.R., Taylor, K.W.: Seasonal incidence of diabetes mellitus. Brit. med. J. 1969 III, $631-633$

4. Craighead, J.E., McLane, M.F.: Diabetes mellitus induction in mice by encephalomyocarditis virus. Science 162, 913-914 (1968)

5. Burch, G.E., Tsui, C.Y., Harb, J.M., Colcolough, H.L.: Pathologic findings in the pancreas of mice infected with coxsackievirus B4. Arch. intern. Med. $128,40-47(1971)$

6. Burch, G.E., Tsui, C.Y., Harb, J.M. : Pancreatic islet cell damage in mice produced by Coxsackie B and encephalomyocarditis viruses. Experientia 28/3, $310-311$ (1972)

7. Coleman, T. J., Gamble, D.R., Taylor, K.W.: Diabetes in mice with Coxsackie B4 virus infection. Brit. med. J. 1973 III, 25-27

8. Harrison, A.K., Bauer, S.P., Murphy, F.A.: Viral pancreatitis; ultrastructural pathological effects of coxsackievirus B3 infections in newborn mouse pancreas. Exp. molec. Path. 17, 206-219 (1972)

9. Howell, S.L., Taylor, K.W.: Potassium ions and the secretion of insulin by islets of Langerhans incubated in vitro. Biochem. J. 108, 17-24 (1968)

10. Gey, G.O., Gey, M.K.: Maintenance of human normal cells in continuous culture preliminary report; cultivation of mesoblastic tumours and normal tissue and notes on methods of cultivation. Amer. J. Cancer 27, $45-76(1936)$

11. Hales, C.N., Randle, P.J.: Immunoassay of insulin with insulin-antibody precipitate. Biochem. J. 88, $137-146(1963)$

12. Robertson, J.S.: The pancreatic lesion in adult mice infected with a strain of pleurodynia virus. Austral. J. exp. Biol. 32, 393-410 (1954)

13. Muntefering, H., Schmidt, W.A.K., Korber, W. : Zur Virusgenese des Diabetes Mellitus bei der weiblichen Maus. Dtsch. med. Wschr. 96, 693-697 (1971)

14. Wellman, C.F., Amsterdam, D., Brancats, P., Volk, B.W.: Fine structure of pancreatic islets of mice infected with the $M$ variant of the encephalomyocarditis virus. Diabetologia 8, 349-357 (1972)

15. Friedman, N.B., Marble, A. : Island hyperplasia in the partially depancreatectomised rat. Endocrinology 29, $577-582(1941)$

16. Craighead, J.E., Steinke, J.: Diabetes-mellitus-like syndrome in mice infected with encephalomyocarditis virus. Amer. J. Path. 63, 119-130 (1971)

17. Taylor, K.W.: Metabolic changes in the islets of Langerhans in relationship to the onset of diabetes mellitus. Diabetologia 8, No. 4, 236-242 (1972)

18. Gamble, D.R., Kinsley, M.L., Fitzgerald, M.G., Bolton, R., Taylor, K.W.: Viral antibodies in diabetes mellitus. Brit. med. J. 1969 III, 627-630

Dr. D.R. Gamble

Public Health Laboratory

West Park Hospital

Epsom, Surrey KT 198 PB

England 